\title{
Environmental parameters affecting biosorption of heavy metals by mixed culture of Aspergillus niger and Aspergillus flavus in industrial wastewater
}

\author{
Ahmed Ismail, Mokhtar S. Beheary and Hanan Ali Gad* \\ Department of Environmental sciences, Faculty of Science, Port Said University, Egypt.
}

Received: 3 January 2017 /Accepted: 6 March 2017

*Corresponding author: hananali553@yahoo.com

\begin{abstract}
This work was conducted to study the effect of some environmental conditions on bioremoval of heavy metals from industrial wastewater by consortium cultures of Aspergillus niger and A. flavus. Many procedures on the effect of incubation period, temperature, $\mathrm{pH}$ and concentration of metals were carried out in the laboratory. Results proved that the high culture growth and maximum heavy metals removal were after 21 days incubation at $30^{\circ} \mathrm{C}, \mathrm{pH}$ of 5.4 and metal concentration at $10 \mathrm{ppm}$. While the lowest culture growth and minimum heavy metals removal were after 7 days incubation at $5{ }^{\circ} \mathrm{C}$, $\mathrm{pH}$ of 10.8 and metal concentration at $100 \mathrm{ppm}$.

Keywords: Aspergillus niger, Aspergillus flavus, Heavy Metals, Industrial waste water, Bioremoval.
\end{abstract}

\section{Introduction}

Increased use of metals and chemicals in industries has resulted in generation of large quantities of effluent that contain high level of toxic heavy metals (Malik, 2004, Chuah et al., 2005). Unlike organic chemicals, metals persist in environment indefinitely posing threats to all the organisms which are exposed to them. Wastewater may be of simple composition if derived from single industry, e.g., electroplating wastewater, or in other cases could be a heterogeneous mix (coming from different industries) of many dissolved metal ions at various $\mathrm{pH}$ with salts, colloidal and particulate matters present as well. Using microorganisms as biosorbents for heavy metals is an attractive alternative to existing methods such as chemical precipitation, chemical oxidation or reduction, electrochemical treatment filtration, ion exchange and membrane technologies for toxicity reduction and recovery of valuable metals from industrial effluents, because of good performance and low cost of biosorbent material (Brierley $\boldsymbol{e t}$ al., 1986) . Asha et al. (2013) stated that bioremediation is the use of biological interventions of biodiversity for mitigation of the environmental pollutants. The term bioremediation has been introduced to describe the process of using biological agents to remove toxic waste from environment .Bioremediation uses biological agents, mainly microorganisms i.e. yeast, fungi or bacteria to clean up 
contaminated soil and water (Strong and Burgess, 2008). The investigation of the efficacy of metal uptake by microbial biomass is essential for the industrial application of biosorption, as it yields information about the equilibrium of the process that is necessary to design the equipment to be employed.

Biosorption process was found to be affected by temperature, $\mathrm{pH}$ of the medium, biomass concentration and metal interference. biosorption process Temperature does not seem to influence biosorption performance in the $20-35{ }^{\circ} \mathrm{C}$ range (Aksu et. al., 1992). $\mathrm{PH}$ seems to be the most important parameter in the biosorption process: it affects the solution chemistry of the metals, the activity of the functional groups in the biomass and competition between metallic ions (Machado et al., 2010). However, Biomass concentration in solution seems to influence specific uptake: for lower values of biomass concentrations, there is an increase in the specific uptake (Fourest and Roux, 1992). Furthermore, biosorption is may be influenced by the presence of other metal ions (Sakaguchi and Nakajima, 1991).

\section{Materials and methods}

\section{1- Antagonistic study of fungal isolates}

The two fungal isolates were isolated from industrial waste water for antagonistic effect on Czapek-Dox agar medium. Disks of $1 \mathrm{ml}$ were taken from 10 days old fungal cultures and placed on Czapek- Dox agar plates where the separated distance of them is $1.5 \mathrm{Cm}$. The plates were incubated at $30^{\circ} \mathrm{C}$ for 10 days the results were recorded.

\section{2-Microbial growth under different culture conditions}

\section{2-1-Effect of incubation period:}

Twelve Erlenmeyer $100 \mathrm{ml}$ conical flasks each containing $50 \mathrm{ml}$ industrial water supplemented with constituents of Czapek DOX medium were sterilized and inoculated with equal volume $(1 \mathrm{ml})$ of fungal spore suspension where $1 \mathrm{ml}$ contains $\left(4 \times 10^{6} \quad \mathrm{CFU}\right)$.Flasks were incubated at $30{ }^{\circ} \mathrm{C}$ for $7,14,21$ and 30 days. Three non-inoculated flasks were used as control. The biosorbents were then removed from the solution by filtration and the supernatant liquid was used to determine the residual metal ions concentration. The results were expressed as (mg) fungaldry weight.

\section{2-2-Effect of Temperature:}

Twelve Erlenmeyer $100 \mathrm{ml}$ conical flasks each containing $50 \mathrm{ml}$ industrial water supplemented with constituents of Cazpek DOX medium were sterilized and inoculated with equal volume $(1 \mathrm{ml})$ of fungal spore suspension where $1 \mathrm{ml}$ contains $\left(4 \times 10^{6}\right.$ CFU). Flasks were incubated at 5, 20, 30 and $40{ }^{\circ} \mathrm{C}$ for 21 days. Three control non inoculated flasks were set up. The biosorbents were then removed from the solution by filtration and the supernatant liquid was used to determine the residual metal ions concentration. The results were expressed as (mg) fungal dry weight

\section{2-3-Effect of $p H$ :}

Twelve $100 \mathrm{ml}$ Erlenmeyer conical flasks each containing $50 \mathrm{ml}$ of industrial waste water supplemented with constituents of Cazpek DOX medium were sterilized and inoculated with equal volume $(1 \mathrm{ml})$ of fungal spore suspension where $1 \mathrm{ml}$ contains $\left(4 \times 10^{6} \mathrm{CFU}\right)$. The $\mathrm{pH}$ of the medium was adjusted to 3.6, 4.6, 5.4, 6.4, $8,9.5$ and 10.8 by using different concentrations of Citric acid and $\mathrm{Na}_{2} \mathrm{HPO} 4$, $\mathrm{Na}_{2} \mathrm{HPO}_{4}$ and $\mathrm{NaH}_{2} \mathrm{PO} 4, \mathrm{Na}_{2} \mathrm{CO}_{3}$ and $\mathrm{NaHCO}_{3}$

Flasks were incubated at $30{ }^{\circ} \mathrm{C}$ for 21 days. Non-inoculated three flasks were used as control. The bio sorbents were then removed from the solution by filtration and the supernatant liquid was used to determine the residual metal ions concentration .The results obtained were recorded as the average of three replications for each $\mathrm{pH}$ measurement. The results were expressed as mg fungal dry weight. 


\section{2-4-Effect of heavy metals concentration:}

Sterilized solutions of different heavy metals concentrations of $10,20,50,100$ $\mathrm{Mg}^{-1}$ of each ( $\mathrm{Fe}, \mathrm{Cu}, \mathrm{Zn}, \mathrm{Cr}$ and $\left.\mathrm{Cd}\right)$ was added separately to each of fourty $100 \mathrm{ml}$ conical flasks each contains $50 \mathrm{ml}$ DOX medium. Flasks then inoculated with with equal volume $(1 \mathrm{ml})$ of fungal spore suspension where $1 \mathrm{ml}$ contains $\left(4 \times 10^{6}\right.$ CFU).Non-inoculated three flasks were used as control. Flasks were incubated at 30 ${ }^{0} \mathrm{C}$ for 21 days. The results were expressed as mg fungal dry weight

\section{3-1-Effect of incubation period:}

Twelve Erlenmeyer $100 \mathrm{ml}$ conical flasks each containing $50 \mathrm{ml}$ industrial water supplemented with constituents of DOX media were sterilized and inoculated with equal volume $(1 \mathrm{ml})$ of fungal spore suspension where $1 \mathrm{ml}$ contains $\left(4 \times 10^{6}\right.$ CFU). Flasks were incubated at $30{ }^{\circ} \mathrm{C}$ for (7, 14, 21 and 30 days).Three noninoculated flasks were used as control. The biosorbents were then removed from the solution by filtration and the supernatant liquid was used to determine the residual metal ions concentration. The degradation of heavy metals ( $\mathrm{Fe}, \mathrm{Cu}, \mathrm{Zn}, \mathrm{Cr}$ and $\mathrm{Cd}$ ) was estimated using atomic absorption spectrophotometer (ASS), flame type multi wave 3000 . The percentage of metal ions removed by microbial cultures was calculated according to the equation:

$\%$ removal $=\left(\mathrm{C}_{\mathrm{i}}-\mathrm{C}_{\mathrm{f}} / \mathrm{C}_{\mathrm{i}}\right) * 100$ where

$\mathrm{C}_{\mathrm{i}}$ : initial metal concentration

$\mathrm{C}_{\mathrm{f}}$ : final or residual metal concentration

\section{3-2-Effect of Temperature}

Twelve Erlenmeyer $100 \mathrm{ml}$ conical flasks each containing $50 \mathrm{ml}$ industrial water supplemented with constituents of DOX media were sterilized and inoculated with equal volume $(1 \mathrm{ml})$ of fungal spore suspension where $1 \mathrm{ml}$ contains $\left(4 \times 10^{6}\right.$ CFU). Flasks were incubated at 5, 20, 30 and $40{ }^{\circ} \mathrm{C}$ for 21 days. Three non-inoculated flasks were used as control. The bio sorbents were then removed from the solution by filtration and the supernatant liquid was used to determine the residual metal ions concentration. The concentration of heavy metals was estimated using atomic absorption spectrophotometer. The percentage of metal ions removed by microbial cultures were calculated

\section{3-3- Effect of $p H$}

Twelve $100 \mathrm{ml}$ Erlenmeyer conical flasks each containing $50 \mathrm{ml}$ of industrial waste water supplemented with constituents of Cazpek DOX medium were sterilized and inoculated with equal volume $(1 \mathrm{ml})$ of fungal spore suspension where $1 \mathrm{ml}$ contains $\left(4 \times 10^{6} \mathrm{CFU}\right)$. The $\mathrm{pH}$ was adjusted to $3.6,4.6,5.4,6.4,8,9.5$ and 10.8. Flasks were incubated at $30{ }^{\circ} \mathrm{C}$ for 21 days. Non-inoculated three flasks were used as control. The biosorbents were then removed from the solution by filtration and the supernatant liquid was used to determine the residual metal ions concentration. The concentrations of heavy metals $(\mathrm{Cu}, \mathrm{Fe}, \mathrm{Cd}, \mathrm{Cr}$ and $\mathrm{Zn})$ were estimated using atomic absorption spectrophotometer. The percentages of metal ions removed by microbial cultures were calculated

\section{Results}

\section{1-Antagonistic effect:}

The antagonistic effect between A. niger and A.flavus showed that there is no antagonistic relation between them

\section{2-Effect of different environmental factors on growth of A. niger and A. flavus in mixed culture}

\section{2-1-Effect of incubation period:}

Results in table (1) showed that the high culture growth $(405 \mathrm{mg} / 50 \mathrm{ml})$ was reported at incubation period of 21 days while the lowest growth (340mg / 50ml) was recorded at incubation period of 7 days. Moreover, after 14 and 30 days of incubation the growth was $374 \mathrm{mg} / 50 \mathrm{ml}$ and $384 \mathrm{mg} / 50 \mathrm{ml}$ respectively.

\section{2-2-Effect of incubation temperature:}

Table 1 illustrated that the high culture growth $(417 \mathrm{mg} / 50 \mathrm{ml})$ was detected after 21 days incubation at $30{ }^{\circ} \mathrm{C}$, while the 
lowest one $(94 \mathrm{mg} / 50 \mathrm{ml})$ was recorded at 5 ${ }^{0} \mathrm{C}$ of the same incubation period. Furthermore, the cultural growth was (344mg $/ 50 \mathrm{ml})$ and $235 \mathrm{mg} / 50 \mathrm{ml}$ at $40{ }^{\circ} \mathrm{C}$ and $20^{\circ} \mathrm{C}$ respectively.

\section{2-3-Effect of pH on mixed culture growth:}

The data in table (1) indicated that the high culture growth $(512 \mathrm{mg} / 50 \mathrm{ml})$ was detected after incubation period of 21 days at incubation $\mathrm{PH} 5.4$ while the lowest growth $(211 \mathrm{mg} / 50 \mathrm{ml})$ was recorded at incubation $\mathrm{PH}$ of 10.8. While at $\mathrm{PH} 3.6$ the cultural growth was $(372 \mathrm{mg} / 50 \mathrm{ml})$, at $\mathrm{PH}$ 4.6 the cultural growth was $(425 \mathrm{mg} / 50 \mathrm{ml})$,at $\mathrm{PH} 6.4$ the cultural growth was recorded $(456 \mathrm{mg} / 50 \mathrm{ml})$, at $\mathrm{PH}$ 8 the cultural growth was $(403 \mathrm{mg} / 50 \mathrm{ml})$ and at $\mathrm{PH} 9.5$ the cultural growth was $\operatorname{recorded}(289 \mathrm{mg} / 50 \mathrm{ml})$.

Table (1): Effect of incubation period, temperature and $\mathrm{PH}$ on growth of A. niger and A. flavus in mixed culture

\begin{tabular}{c|c|c|c|c|c|c|c|c|c|c|c|c|c|c|c}
\hline \multirow{2}{*}{ factor } & \multicolumn{3}{|c|}{$\begin{array}{c}\text { Incubation period } \\
\text { (day) }\end{array}$} & \multicolumn{4}{c|}{$\begin{array}{c}\text { Temp } \\
(\mathbf{0} \mathbf{C})\end{array}$} & \multicolumn{1}{c}{ PH } \\
\cline { 2 - 13 } $\begin{array}{l}\text { Growth } \\
(\mathrm{mg} / 50 \mathrm{ml})\end{array}$ & 7 & 14 & 21 & 30 & 5 & 20 & 30 & 40 & 3.6 & 4.6 & 5.4 & 6.4 & 8 & 9.5 & 10.8 \\
\hline
\end{tabular}

\section{2-4-Effect of different concentrations of heavy metals on mixed culture growth:}

The results in table (2) indicated that for $\mathrm{Cu}^{2+}$ the highest culture growth $(405 \mathrm{mg}$ $150 \mathrm{ml}$ ) was reported after incubation period of 21 days at concentration $10 \mathrm{ppm}$ whereas the lowest growth $(308 \mathrm{mg} / 50 \mathrm{ml})$ was recorded at concentration of $100 \mathrm{ppm}$. With the increase of copper concentration up to $20 \mathrm{ppm}$ and 50ppm the cultural growth was taken median value of $329 \mathrm{mg} / 50 \mathrm{ml}$ and $311 \mathrm{mg} / 50 \mathrm{ml}$ respectively.

For $\mathrm{Zn}^{2+}$ the high culture growth $(442 \mathrm{mg} / 50 \mathrm{ml})$ was reported after incubation period of 21 days at concentration of $10 \mathrm{ppm}$ while the lowest growth $(359 \mathrm{mg} / 50 \mathrm{ml})$ was recorded at concentration of $100 \mathrm{ppm}$. The cultural growth becomes $(403 \mathrm{mg} / 50 \mathrm{ml})$ and $(326 \mathrm{mg} / 50 \mathrm{ml})$ at concentration of $20 \mathrm{ppm}$ and $50 \mathrm{ppm}$ respectively. Likewise, the highest $(382 \mathrm{mg} / 50 \mathrm{ml})$ and the lowest $(324 \mathrm{mg} / 50 \mathrm{ml})$ culture growth were reported after incubation period of 21 days at $\mathrm{Fe}^{2}$ concentration of $10 \mathrm{ppm}$ and 100 ppm respectively. By the way, the cultural growth of $342 \mathrm{mg} / 50 \mathrm{ml}$ and $326 \mathrm{mg} / 50 \mathrm{ml}$ was recorded at $\mathrm{Fe}^{2}$ concentration of 20 ppm and 50ppm respectively.

For $\mathrm{Cd}{ }^{2+}$ the high culture growth $(403 \mathrm{mg} / 50 \mathrm{ml})$ was reported after incubation period of 21 days at concentration $10 \mathrm{ppm}$ while the lowest growth $(332 \mathrm{mg} / 50 \mathrm{ml})$ was recorded at concentration $100 \mathrm{ppm}$. The cultural growth was recorded $(376 \mathrm{mg} / 50 \mathrm{ml})$ at concentration of $20 \mathrm{ppm}$ and $(336 \mathrm{mg} / 50 \mathrm{ml})$ at concentration of $50 \mathrm{ppm}$.

And for $\mathrm{Cr}^{5+}$ the high culture growth $(398 \mathrm{mg} / 50 \mathrm{ml})$ was reported after incubation period of 21 days at concentration $10 \mathrm{ppm}$ while the lowest growth $(342 \mathrm{mg} / 50 \mathrm{ml})$ was recorded at concentration $100 \mathrm{ppm}$. The cultural growth was recorded $(396 \mathrm{mg} / 50 \mathrm{ml})$ at concentration of $20 \mathrm{ppm}$ and $(348 \mathrm{mg} / 50 \mathrm{ml})$ at concentration of $50 \mathrm{ppm}$.

Table (2): Effect of different concentrations of heavy metals on mixed culture growth

\begin{tabular}{l|c|c|c|c|c}
$\begin{array}{c}\text { Heavy } \\
\text { metals } \\
\text { Conc. }\end{array}$ & Cu & Zn & Fe & Cd & Cr \\
\hline $\mathbf{1 0}$ & 405 & 442 & 382 & 403 & 398 \\
$\mathbf{2 0}$ & 329 & 403 & 342 & 376 & 396 \\
$\mathbf{5 0}$ & 311 & 389 & 326 & 336 & 348 \\
$\mathbf{1 0 0}$ & 308 & 359 & 324 & 332 & 342 \\
\hline
\end{tabular}

\section{3-Effect of different cultural factors on biosorption ofheavy:3-1-Effect of incubation period on heavy metals removal:}

Results in figure (1) showed that the highest uptake of heavy metals was detected after incubation period of 21 days $\mathrm{Cu}^{+2}(20.7 \mathrm{mg} / \mathrm{m}), \mathrm{Fe}^{+2}(28.44 \mathrm{mg} / \mathrm{m}) \mathrm{Cd}^{+2}$ $(14.34 \mathrm{mg} / \mathrm{m})$ and $\mathrm{Zn}^{+2}(14.15 \mathrm{mg} / \mathrm{m})$ while the lowest uptake of heavy metals was detected after incubation period of 7 days $\mathrm{Cu}^{+2}(9.58 \mathrm{mg} / \mathrm{m}), \mathrm{Fe}^{2+}(21.34 \mathrm{mg} / \mathrm{m}) \mathrm{Cd}^{+2}$ $(15.2 \mathrm{mg} / \mathrm{m})$ and $\mathrm{Zn}^{+2}(12.79 \mathrm{mg} / \mathrm{m})$ heavy metals removal was recorded after 7 days. 


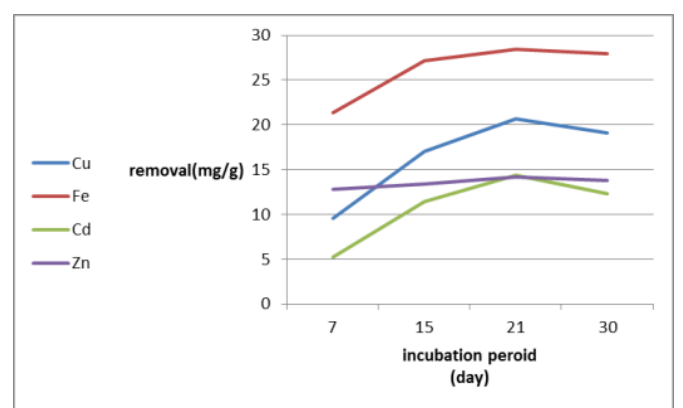

Figure (1): Effect of incubation period on heavy metals removal

\section{3-2-Effect of temperature on heavy metals removal}

Results in figure (2) showed that the highest uptake of heavy metals was detected after incubation period of 21 days at incubation temperature of $30{ }^{0} \mathrm{C} \mathrm{Cu}^{+2}$ $(15.76 \mathrm{mg} / \mathrm{m}), \mathrm{Fe}^{+2}(38.63 \mathrm{mg} / \mathrm{m}) \mathrm{Cd}^{+2}(14$ $\mathrm{mg} / \mathrm{m})$ and $\mathrm{Zn}^{+2}(17.77 \mathrm{mg} / \mathrm{m})$ while the lowest uptake of heavy metals was detected after incubation temperature of 5 ${ }^{0} \mathrm{C}$ days $\mathrm{Cu}^{+2}(1.8 \mathrm{mg} / \mathrm{m}), \mathrm{Fe}^{2+}(9.16 \mathrm{mg} / \mathrm{m})$ $\mathrm{Cd}^{+2}(1.93 \mathrm{mg} / \mathrm{m})$ and $\mathrm{Zn}^{+2}(3.01 \mathrm{mg} / \mathrm{m})$ heavy.

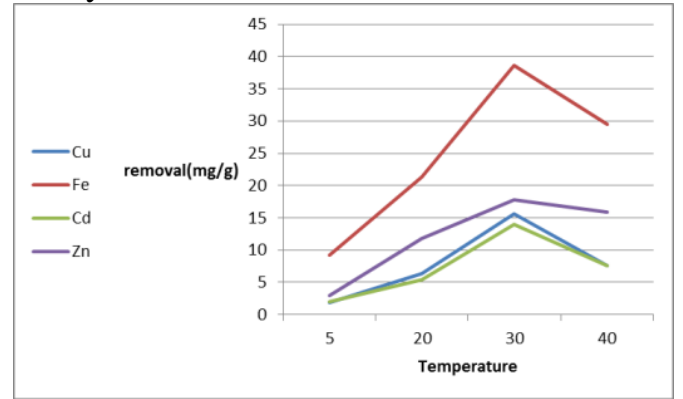

Figure (2): effect of temperature on heavy metals removal

\section{3-3-Effect of pH on heavy metals removal}

The data presented in figure (3) show that $\mathrm{Cu}^{+2}$ was recorded the highest bio removal $(20.19 \mathrm{mg} / \mathrm{m})$ after incubation period of 21 days at incubation $\mathrm{pH}$ of (5.4) while the lowest bio removal $(6.67 \mathrm{mg} / \mathrm{m})$ at incubation $\mathrm{pH}$ of (10.8), where $\mathrm{Zn}^{+2}$ was recorded the highest bio removal (20.97 $\mathrm{mg} / \mathrm{m}$ ) after incubation period of 21 days at incubation $\mathrm{pH}$ of (5.4) while the lowest bio removal $(12.94 \mathrm{mg} / \mathrm{m})$ at incubation $\mathrm{pH}$ of (10.8). Also $\mathrm{Fe}^{+2}$ was recorded the highest bio removal $(76.98 \mathrm{mg} / \mathrm{m})$ after incubation period of 21 days at incubation $\mathrm{pH}$ of (5.4) while the lowest bio removal $(47.95 \mathrm{mg} / \mathrm{m})$ at incubation $\mathrm{pH}$ of $(10.8) . \mathrm{Cd}^{+2}$ was recorded the highest bio removal (4.36 $\mathrm{mg} / \mathrm{m}$ ) after incubation period of 21 days at incubation $\mathrm{pH}$ of (5.4) while the lowest bio removal $(3.12 \mathrm{mg} / \mathrm{m})$ at incubation $\mathrm{pH}$ of (10.8)

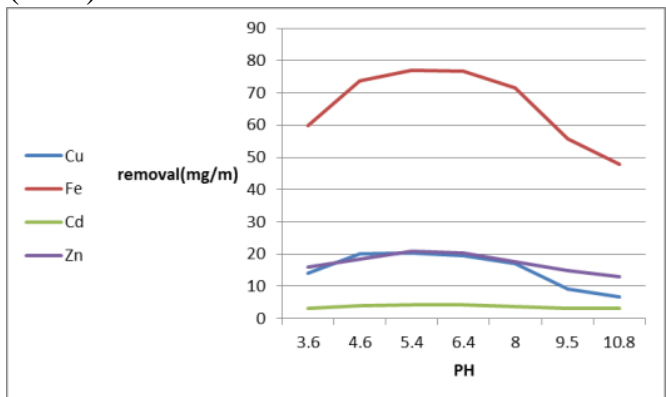

Figure (3): Effect of incubation $\mathrm{pH}$ on heavy metals removal

\section{Discussion}

Cultural age is considered as an important microbial factor that affects metals uptake. In the present study maximum heavy metal removal by fungal consortium occurred after three weeks incubation. At this incubation period the fungal growth was $(405 \mathrm{mg} / \mathrm{l})$ and heavy metals removal were in the following order $\mathrm{Cu}^{2+} 20.7 \mathrm{mg} / \mathrm{g}$, $\mathrm{Fe}^{2+} 28.44 \mathrm{mg} / \mathrm{g}, \mathrm{Cd}^{2+} 14.34 \mathrm{mg} / \mathrm{g}$, and $\mathrm{Zn}^{2+}$ $14.15 \mathrm{mg} / \mathrm{g}$. This is possibly due to the presence of many highly active enzymes at this growth phase, during which cells are at their most metabolically active stage).A similar result was reported by (Mondal, $\boldsymbol{e} t$ al., 2008).

The temperature influence on metal uptake was pronounced where with their increases from $5,20,30$ and $40^{\circ} \mathrm{C}$, the uptake level was increased gradually up to $30^{\circ} \mathrm{C}$ where the maximum uptake of $\mathrm{Cu}^{2+}, \mathrm{Fe}^{2+}, \mathrm{Cd}^{2+}$, and $\mathrm{Zn}^{2+}$ was $15.76 \mathrm{mg} / \mathrm{g}$, $38.63 \mathrm{mg} / \mathrm{g}, 14 \mathrm{mg} / \mathrm{g}$, and $17.77 \mathrm{mg} / \mathrm{g}$ respectively. Conversely, at temperature of $40^{\circ} \mathrm{C}$ the uptake level was declined in the following order $\left(\mathrm{Cu}^{2+} 7.61 \mathrm{mg} / \mathrm{g}, \mathrm{Fe}^{2+} 29.5\right.$ $\mathrm{mg} / \mathrm{g}, \quad \mathrm{Cd}^{2+} 7.53 \mathrm{mg} / \mathrm{m}$, and $\mathrm{Zn}^{2+} 15.94$ $\mathrm{mg} / \mathrm{m}$. By the way the fungal growth was reduced from, $417 \mathrm{mg} / 50 \mathrm{ml}$ at $30^{\circ} \mathrm{C}$ to $344 \mathrm{mg} / 50 \mathrm{ml}$ at $40{ }^{\circ} \mathrm{C}$. Higher temperatures usually enhance sorption due to increased surface activity and kinetic energy of the solute (Sag and Kutsal, 2000). Conversely, high temperature was reported to reduce biosorption capacity of the biomass by causing a Physical damage to the biosorbent and exothermic nature of some adsorption processes in (Srivastava 
and Thakur, 2006). It is always desirable to conduct biosorption at room temperature, as this condition is easy to replicate (Vijayaraghavan and Yeoung, 2008)

The pH considered as one of the most effective parameters in biosorption of heavy metals, the mixed culture was grown in different $\mathrm{pH}$ values, it was found that best $\mathrm{pH}$ used for broth culture growth (512 $\mathrm{mg} / \mathrm{l}$ ) and heavy metals uptake was $\mathrm{pH} 5.4$ where the uptake level was in the following order; $\mathrm{Zn}^{2+}(20.97 \mathrm{mg} / \mathrm{g}), \mathrm{Fe}^{2+}(76.98$ $\mathrm{mg} / \mathrm{g}), \mathrm{Cu}^{2+}(20.19 \mathrm{mg} / \mathrm{g})$ and $\mathrm{Cd}^{2+}(4.36$ $\mathrm{mg} / \mathrm{g}$ ). In fact, the dependence of metal uptake on $\mathrm{pH}$ is related to both surface functional groups present on biomass and metal chemistry in solution. Generally, at low $\mathrm{pH}$ of 2.0-3.0, the surface ligands are closely associated with the hydronium ions $\left(\mathrm{H}_{3} \mathrm{O}^{+}\right)$and restricted the approach of metal cations. As a result of repulsive force causes decreased metal sorption takes place at low $\mathrm{pH}$. Correspondingly, the $\mathrm{pH}$ dependency of metals uptake by $A$. niger and $A$. flavus is due to association and dissociation of certain functional groups like carboxyl and hydroxyl groups, where at low $\mathrm{pH}$, most of the carboxylic groups is not dissociated and cannot bind the metal ions to fungal cell wall (Choudhary and Sar, 2009). On the contrary, at high $\mathrm{pH}$ value metals get precipitate, where cadmium ions precipitate as $\mathrm{Cd}(\mathrm{OH})_{2}$ and trivalent chromium ions precipitate as $\mathrm{Cr}$ $(\mathrm{OH})_{3}$. This causes very low biosorption of metal ions in high $\mathrm{pH}$ value (Pinoa et al., 2006). The metal binding sites on cell surface and availability of metal ions in solution are affected by $\mathrm{pH}$. Alike, Johncy et al., 2010 stated that, at low $\mathrm{pH}$, the cell surface sites are closely linked to the $\mathrm{H}^{+}$ ions, thereby making these unavailable for metal cations. Consequently, with increase in the $\mathrm{pH}$, there is an increase in ligand with negative charges which results in increased binding of cations. The increase in $\mathrm{pH}$ causes increased negative charge on cell surface which favoured electrochemical attraction and adsorption of metals 0 . Therefore, the optimal $\mathrm{pH}$ for biosorption of heavy metals by fungal biomass is between 5.0-5.2 (Shankar et al., 2007).

The data revealed that there was no significant decrease in fungal biomass, with increasing the heavy metals concentration.
Biomasses recorded at $\mathrm{Cu}$ concentration of $10,20,50$ and $100 \mathrm{mg} / \mathrm{l}$ were $405,329,311$, $308 \mathrm{mg} / 50 \mathrm{ml}$ respectively. For $\mathrm{Zn}$ concentration of $10,20,50$ and $100 \mathrm{mg} / \mathrm{l}$ the biomasses recorde were 442, 403, 389, $359 \mathrm{mg} / 50 \mathrm{ml}$ respectively. Likewise, the biomasses at Fe concentration of 10, 20, 50 and $100 \mathrm{mg} / \mathrm{l}$ were $382,342,326,324 \mathrm{mg}$ $150 \mathrm{ml}$ respectively. For $\mathrm{Cd}$ concentration of $10,20,50$ and $100 \mathrm{mg} / \mathrm{l}$ the biomasses were $403,376,336,332 \mathrm{mg} / 50 \mathrm{ml}$ respectively, whereas for $\mathrm{Cr}$ concentration of 10, 20, 50 and $100 \mathrm{mg} / \mathrm{l}$ the biomasses were 398, 396, 348 and $342 \mathrm{mg} / 50 \mathrm{ml}$ respectively. By the way, Atuanya and Oseghu (2006) found that as the concentration of lead increased from $10 \mathrm{mg} \mathrm{L}-1$ to $1000 \mathrm{mg} \mathrm{L}-1$, a decrease in biomass of fungi was recorded. A like, Siham (2007) stated that a decrease in biomass was observed as a result of increases in the concentration of metal ions. She isolated Alternaria clamydospore, Aspergillus niger, A. oryzae, A. parasiticus, A. tamari, A. ustus, Fusarium sp., Penicillium glabarum from metal contaminated sites which were found tolerant to lead.

(Shivakumar, 2014) stated that A. niger and $A$. flavus showed almost similar uptake ability of metals. A. niger showed high $\mathrm{Pb}$ (75\%) accumulation followed by $\mathrm{Zn}$ $(49 \%)>\mathrm{Cu}(45 \%)>\mathrm{Cr}(41 \%)>\mathrm{Ni}(25 \%)$ and $A$. flavus showed high $\mathrm{Pb}(82 \%)$ accumulation followed by $\mathrm{Zn}(40 \%)>\mathrm{Cu}$ $(34 \%)>\mathrm{Ni} \quad(20 \%)$.Bioaccumulation efficiency of some metals decreased at high metal concentrations due to saturation of the biosorbent (Rao et al., 2005).

\section{Conclusion and recommendation}

The fungal consortium of $A$. flavus and $A$. niger was able to remove $\mathrm{Fe}, \mathrm{Cu}, \mathrm{Cr}$ and $\mathrm{Cd}$ from solution. Therefore, it is proposed to use them as an effective biosorbent agent for removal of heavy metals

\section{References}

Asha; Latha, P.; and Sandeep , Reddy S.; (2013). Review on BioremediationPotential Tool for Removing Environmental Pollution. International Journal of Basic and Applied Chemical Sciences: 2277- 2073 
Asku; Z. (1992). The biosorption of Cu (II) by C. vulgaris and Z. ramigera. Environ. Tech. 13:579-586.

Atuanya; .E. I. and Oseghe ; E. O. (2006). Lead contamination and microbial lead tolerance in soils at major road junctions in Benin City". J. Applied Sci. Environ. Manage. 10: 99-104.

Brierley J. A.; C. L. Brierley and G. M. Goyak (1986). A new wastewater treatment and metal recovery technology. In: Fundamental and Applied Biohydrometallurgy; Eds. R.W. Lawrence; R.M.R. Branion and G. Ebner; Elsevier; Amsterdam 291-303 .

Choudhary; S. and Sar P. (2009). Characterization of a metal resistant Pseudomonas sp. isolated from uranium mine for its potential in heavy metal $(\mathrm{Ni} 2+$; $\mathrm{Co} 2+; \mathrm{Cu} 2+$; and $\mathrm{Cd} 2+$ ) sequestration. Bioresource Technology; 100: 2482-2492.

Chuah T. G. ; A. Jumasiah; I. Azni ; S. Katayon ; and S. Y. T. Choong (2005). Rice husk as a potentially low-cost biosorbent for heavy metal and dye removal: an overview. Desalination 175: 305-316. http://dx.doi.org/10.1016/j.desal.2004.10.0 14

Fourest, E. and Roux. J. C. (1992). Heavy metal biosorption by fungal mycelial by-products: mechanism and influence of $\mathrm{pH}$. Applied Microbiology Biotechnology

Johncy, M. R.; Hemambika.; B. Hemapriya and Rajesh Kannan, V. (2010). Comparative assessment of heavy metal removal by immobilized and dead bacterial cells". A biosorption approach. African Journal of Environmental Science and Technology; 04: 77-83.

Machado, M.D.; Soares, E.V.; Helena M.V.M; and Soares, H. M. V. M.; (2010). Removal of heavy metals using a brewer's yeast strain of Saccharomyces cerevisiae: Chemical speciation as a tool in the prediction and improving of treatment efficiency of real electroplating effluents." J. Hazard. Mat.; Vol. 180; pp. 347-353.

Malik, A.; (2004). Metal bioremediation through growing cells. Environ Int.; 30: 261-278.
Mondal, P., Maumder C. B. and Mohanty, B. (2008). Treatment of arsenic contaminated water in a laboratory scale up flow biocolumn reactor. J. Hazard. Material. 153:126-145.

Pinoa, G. H., de Mesquitaa; L. M. S.; Torema M. L. and Pinto G. A .S. (2006).Biosorption of Heavy Metals by Powder of Green Coconut Shell. Separation Science and Technology. 41: 3141-3153.

Rao, K.R.; Rashmi, K.; Latha, J. N. L. and Mohan, P. M. (2005). Bioremediation of toxic metal ions using biomass of Aspergillus fumigatus from fermentative waste". Indian Journal of Biotechnology. 4: 139-143.

Sag, Y. and Kutsal, T.; (2000). Determination of the biosorption activation energies of heavy metal ions on Zoogloearaigera and Rhizopus arrhizus. Process Biochemistry 35: 801-807.

Sakaguchi, T. and Nakajima, A.; (1991). Accumulation of heavy metals such as uranium and thorium by microorganisms. Smith RW; Misra M. (Eds.); Mineral Bioprocessing. The Minerals; Metals and Materials Society.

Shankar, C.; Sridevi, D.; Joonhong, P.; Michael; D.and Kaliannan, T. (2007). Biosorption of chromium and nickel by heavy metal resistant fungal and bacterial isolates. Journal of Hazardous Materials. 146: 270-277.

Shivakumar, C.K.; Thippeswamy .B;and Krishnappa. M. (2014). Optimization of Heavy Metals Bioaccumulation in Aspergillus niger and Aspergillus flavus ISSN 2277-386X Original Article

Siham, A. K. A.; (2007). Effect of lead and copper on the growth of heavy metal resistance fungi isolated from second industrial city in Riyadh; Saudi Arabia. J. Applied Sci. 7: 1019-1024.

Strong, P.J.; and Burgess J.E.; (2008). Treatment methods for wine related distillery wastewaters. A review. Biorem. Jou.; 12: pp 7087.

Vijayaraghavan, K. and Yeoung, S.Y.; (2008). Bacterial biosorbents and biosorption. Biotechnology Advances 26: 266-291. 
عنوان البحث: العوامل البيئية التي تؤثر على الازاله البيولوجية للمعادن الثقيلة من مياه الصرف الصناعى باستخدام

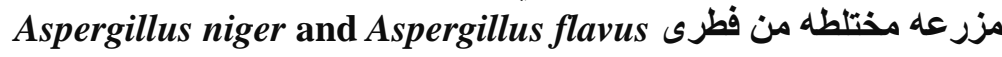

أحمد اسماعيل عبد القادر ، مختار سامي بحيرى ، حنان على حسن جاد قسم علوم البيئه ــكلية العلوم - جامعة بورسعيد

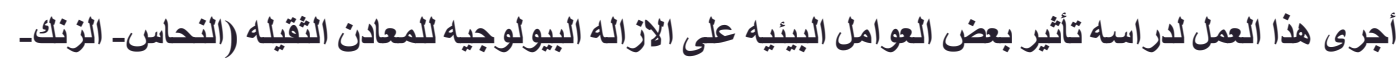

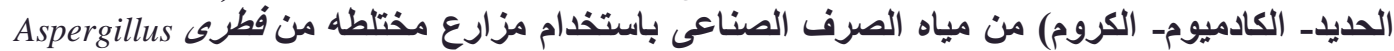
ودiger and Aspergillus flavus

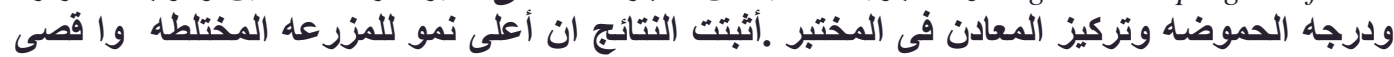

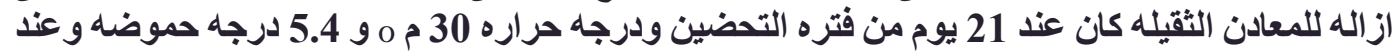

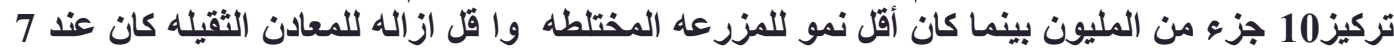

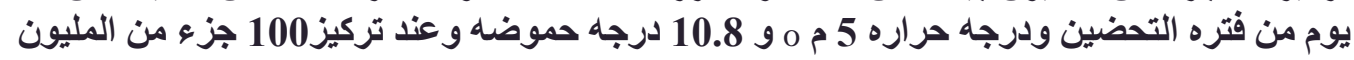

